В.А. Зверев

С.В. Косыгина*

Динамика численности и воспроизводство населения Тобольской губернии во время Первой мировой войны

DOI: 10.31518/2618-9100-2020-1-13

УДК 930.2+94(3)

Выходные данные для цитирования:

Зверев В.А., Косыгина С.В. Динамика численности и воспроизводство населения Тобольской губернии во время Первой мировой войны // Исторический курьер. 2020. № 1 (9). С. 154-163. URL: http://istkurier.ru/data/2020/ISTKURIER-2020-113.pdf
V.A. Zverev

S.V. Kosygina*

\section{Population Dynamics and Reproduction of the Population of Tobolsk Provincete During the First World War}

\author{
DOI: 10.31518/2618-9100-2020-1-13
}

How to cite:

Zverev V.A., Kosygina S.V. Population Dynamics and Reproduction of the Population of Tobolsk Provincete During the First World War // Historical Courier, 2020, No. 1 (9), pp. 154-163. [Available online:] http://istkurier.ru/data/2020/ISTKURIER2020-1-13.pdf

Abstract. The article focuses on spatial analysis of Perm province's commercial and manufacturing development in the early $20^{\text {th }}$ century. Perm province, the biggest and most eastern province in European Russia, occupied a vast territory of $332.000 \mathrm{sq} \mathrm{km}$ and had a population of almost 3 mln people according to the 1897 census. In administrative terms, it was composed of 12 uezds (sub-subprovinces), which spread along both slopes of the Ural Mountains and differed by size, population and economy. While the metal production and mining industry in the region attracted many scholars, commercial and manufacturing development in the early $20^{\text {th }}$ century and its spatial characteristics are understudied. On the basis of local statistics the article analyzes the uyezds' commercial and manufacturing development using the number of its businesses per 1.000 citizens as the main indicator. Economy theory and spatial analysis helped to study and visualize Perm province's commercial and manufacturing development on sub-provincial level, finding and interpreting regional differences. In the course of the study it was found out that: in terms of commerce and manufacturing Perm and Verkhotur'e sub-provinces turned out to be more developed than Ekaterinburg sub-province, which was considered the strongest in the province. All the sub-provinces experienced significant growth in 1905, in contrast to the rest of Russia experiencing severe crisis. Commerce and manufacturing stagnation in Perm province after 1905 developed along with the business' concentration in just few sub-provinces. The high harvest of 1904 led to a rapid growth of the economy in the Kungur sub-province despite the general decrease of agrarian sub-provinces. The author assumes that its location on the Trans-Siberian railway made Kungur the province's grain trade center. In contrast, Irbit and Shadrinsk subprovinces, that hosted the biggest fairs, experienced decrease of its local commerce and manufacturing development, likely being suppressed by the big annual trade events.

Keywords: economic history; Perm province; Ural around 1900; economic area; economy of Russian empire; factory sector.

The article has been received by the editor on 31.12.2019.

Full text of the article in Russian and references in English are available below.

\footnotetext{
* Зверев Владимир Александрович, доктор исторических наук, Новосибирский государственный педагогический университет, Новосибирск, Россия, e-mail: sosna232@yandex.ru

Косыгина Светлана Валерьевна, аспирант, Новосибирский государственный педагогический университет, Новосибирск, Россия, e-mail: cool.balanar2014@yandex.ru

Zverev Vladimir A., Doctor of Historical Sciences, Novosibirsk State Pedagogical University, Novosibirsk, Russia, email: sosna232@yandex.ru

Kosygina Svetlana V., Post-Graduate Student, Novosibirsk State Pedagogical University, Novosibirsk, Russia, e-mail: cool.balanar2014@yandex.ru
} 
Аннотация. В исторической демографии слабо исследованным остается процесс воспроизводства населения России и ее регионов во время Первой мировой войны, последние годы которой совпали с революционными потрясениями и началом Гражданской войны. В настоящей статье характеризуется динамика общей численности и естественного движения населения Тобольской губернии в период войны, в сравнении с предвоенным временем. Используются записи церковных метрических книг Тарского уезда за 1912, 19141918 гг., частично компенсирующие отсутствие обобщающих статистических данных о масштабах воспроизводства населения в губернии. Установлено, что в 1914 и 1915 гг. в губернии продолжалось происходившее в довоенный период увеличение общей численности населения, но в 1916-1917 гг. количество жителей уменьшалось вследствие мобилизации на фронт военнообязанных лиц. Поток беженцев из прифронтовой полосы, депортация военнопленных, концентрация на территории губернии вооруженных формирований в некоторой степени компенсировали сокращение численности населения. В 1914 г. параметры брачности, рождаемости, смертности населения соответствовали стандартам начальной фазы демографического перехода и еще не испытали негативного воздействия войны. Расчеты по данным метрических книг Тарского уезда показали, что в 1915-1916 гг. здесь уровень брачной активности снижался, но в 1917-1918 гг. стихийная демобилизация армии, победа революции, выход России из войны создали у значительной части населения иллюзию, что трудности уходят в прошлое, и возник компенсаторный подъем брачности. Рождаемость после начала войны снижалась и достигла минимума в 1917 г. на уровне в два раза меньшем, чем в довоенном 1912 г. Однако возвращение домой части мужчин и оживление брачной активности привели к тому, что в 1918 г. рождаемость поднялась до довоенных параметров. Экстремальная обстановка провоцировала усиление смертности, и своего пика она достигла в 1915 г. Однако господствующей тенденцией в период войны стало все же сокращение смертности вследствие спада рождаемости. Естественный прирост населения в годы войны уменьшался и в 1916-1917 гг. составил всего 20-30 \% от довоенного уровня. Однако в 1918 г. вследствие всплеска компенсаторной рождаемости прирост на четверть превысил довоенный уровень. Относительно благоприятная демографическая ситуация, сложившаяся в 1918 г., в исторической перспективе оказалась передышкой в ходе демографического кризиса, продолжавшегося до 1923 г.

Ключевые слова: Тобольская губерния; Тарский уезд; 1914-1918 гг.; народонаселение; численность населения; воспроизводство населения; естественное движение населения; церковные метрические книги.

\section{Актуальность, историографический контекст и задачи исследования}

На современном этапе развития социальных наук довольно динамично развивается область исторической демографии. Усилиями преимущественно новосибирских ученых, в частности, созданы обобщающие труды о воспроизводстве населения в Сибирском регионе на протяжении длительного периода XIX - начала XXI в. ${ }^{1}$ В то же время остается немало слабоизученных сюжетов региональной демографической истории. Среди них - воспроизводство населения во время политических потрясений периода Первой мировой войны, Великой российской революции и Гражданской войны. Обстановка этих лет дезорганизовала учет демографических событий, часть материалов, собранных вопреки обстоятельствам, погибла в огне военного и гражданского противоборства, поэтому историки сегодня имеют весьма отрывочные и

\footnotetext{
${ }^{1}$ Демографическая история Западной Сибири. Новосибирск, 2017; Зверев В.А. «Ну, посчитаемся своими»: демографические и миграционные процессы в Азиатской России XIX - начала XX в. // Проблемы исторической демографии Сибири. Новосибирск, 2011. Вып. 2. С. 42-68; Население [Сибири] / В.А. Зверев, В.А. Исупов, И.Б. Карпунина [и др.] // Историческая энциклопедия Сибири. Новосибирск, 2010. Т. 2. С. 434441; и др.
} 
неполные данные о масштабах и хронологической динамике брачности, рождаемости, смертности и естественного прироста населения в 1914-1922 гг.

Наличие ограниченных возможностей для изучения демографической ситуации периода политических потрясений начала XX в. характерно, в частности, и для истории Тюменского региона. Возможно, это одна из причин, по которой ученые, создавшие специальные труды о развитии Тобольской губернии в годы Первой мировой войны (П.И. Рощевский, В.Н. Меньщиков, С.Ю. Шишкина и др.), не ставили перед собой специфических историкодемографических задач и ограничились в основном разработкой политических, социальноэкономических, социокультурных аспектов темы ${ }^{2}$. Впрочем, в упомянутых трудах приводится фактическая информация и имеются полезные для нашей работы выводы о динамике общей численности населения, плачевном состоянии трудовых ресурсов в военное время.

Основная задача данной статьи заключается в раскрытии специфических для предмета исторической демографии параметров динамики воспроизводства населения - изменений показателей брачности, рождаемости, смертности и естественного прироста населения Тобольской губернии в 1914-1918 гг. В тесной связи с этим вопросом характеризуется также происходившая в обстановке войны трансформация общей численности населения губернии. Демографическая ситуация военного периода раскрывается в сравнении с последними предвоенными годами. При этом используются записи церковных метрических книг Тарского уезда, частично компенсирующие отсутствие обобщающих статистических данных о масштабах естественного движения населения в губернии за 1915-1918 гг.

\section{Воспроизводство населения в первый год войны}

Общие коэффициенты естественного движения населения на территории Тобольской губернии за последние три предвоенных года (1911-1913) можно вычислить по официальным данным текущего административного учета населения. На каждую 1000 человек населения в это время ежегодно заключалось 8,2 брака; рождалось 53,9 младенца и умирало 37,6 душ, что давало естественный прирост, равный 16,3 \% ${ }^{3}$. Коэффициент естественного прироста, превышающий 15-20\%о, можно трактовать как важное проявление начальной стадии демографической модернизации общества. Мы видим, что накануне Первой мировой войны коэффициент прироста в Тобольской губернии был очень высоким, что говорит о наметившемся начале демографического перехода.

Судя по данным Управления главного врачебного инспектора Министерства внутренних дел Российской империи, 1 января 1914 г. в Тобольской губернии насчитывалось 2103294 постоянных жителя. По сравнению с началом 1912 г. общая численность населения выросла здесь на $3,2 \%{ }^{4}$. Те же официальные данные свидетельствуют о том, что в первый военный год в губернии было заключено 17696 браков, родилось 117379 детей, умерло 80174 человека, естественный прирост населения составил 37205 душ 5 . Рассчитанные с учетом этих сведений общие коэффициенты естественного движения населения выглядели так: брачность - 8,4 \%о;

\footnotetext{
${ }^{2}$ Меньщиков В.Н. Экономическое и социокультурное развитие Тобольской губернии в период Первой мировой войны, 1914-1917 гг.: автореф. дис. ... канд. ист. наук. Омск, 2001; Рощевский П.И. Тобольская губерния в годы Первой мировой империалистической войны (1914-1917) // Вопросы истории Западной Сибири. Тюмень, 1974. Т. 3. Вып. 1. С. 24-33; Шишкина С.Ю. Провинция и война: Тобольская губерния в годы Первой мировой войны (август 1914 - февраль 1917). Тюмень, 2006; и др.

${ }^{3}$ Подсчитано по: Зверев В.А. «Любо - так к венцу»: брачность русского населения Сибири во второй половине XIX - начале XX в. // Православные традиции в народной культуре восточнославянского населения Западной Сибири в конце XIX - XX в. Новосибирск, 2005. С. 9; Зверев В.А. «Родится на смерть, умрет на живот»: естественное движение населения Сибири за 30 лет (1884-1914) // Современное историческое сибиреведение XVII - начала XX в. Барнаул, 2008. Вып. 2. С. 111. Символ «\%» (промилле) здесь и далее означает «на каждую 1000 человек населения».

${ }^{4}$ Подсчитано по: Отчет о состоянии народного здравия и организации врачебной помощи в России за 1911 г. СПб., 1913. Ч. 2. С. 98-99; Отчет о состоянии народного здравия и организации врачебной помощи в России за 1913 г. Пг., 1915. С. 98-99 (3-я паг.).

${ }^{5}$ Обзор Тобольской губернии за 1914 г. Тобольск, 1916. С. 6.
} 
рождаемость - 55,5; смертность - 37,9; естественный прирост - 17,6 \% ${ }^{6}$. Эти показатели близки к предвоенным, будучи, пожалуй, даже несколько предпочтительными по сравнению с ними. Несомненно, начавшаяся в июле 1914 г. война не успела негативно сказаться на демографической сфере жизни сообщества тоболяков, в ней продолжались прогрессивные изменения.

Позитивная ситуация в сфере естественного движения населения сказалась на росте общей численности населения губернии. По состоянию на 1 января 1915 г. она равнялась 2125692 человекам, увеличившись за предыдущий год на 22398 душ․ Таким образом, в 1914 г. реальный прирост общей численности населения Тобольской губернии составил $1,1 \%$, хотя при достигнутом уровне естественного прироста можно было ожидать увеличения количества тобольских жителей на 1,8 \%. Недостающие 0,7 \%, или около 15 тыс. человек «поглотил» отрицательный баланс механического движения населения, ведь во второй половине 1914 г. началась массовая воинская мобилизация мужского населения, оно направлялось в западные районы страны к театрам военных действий (рис. 1).

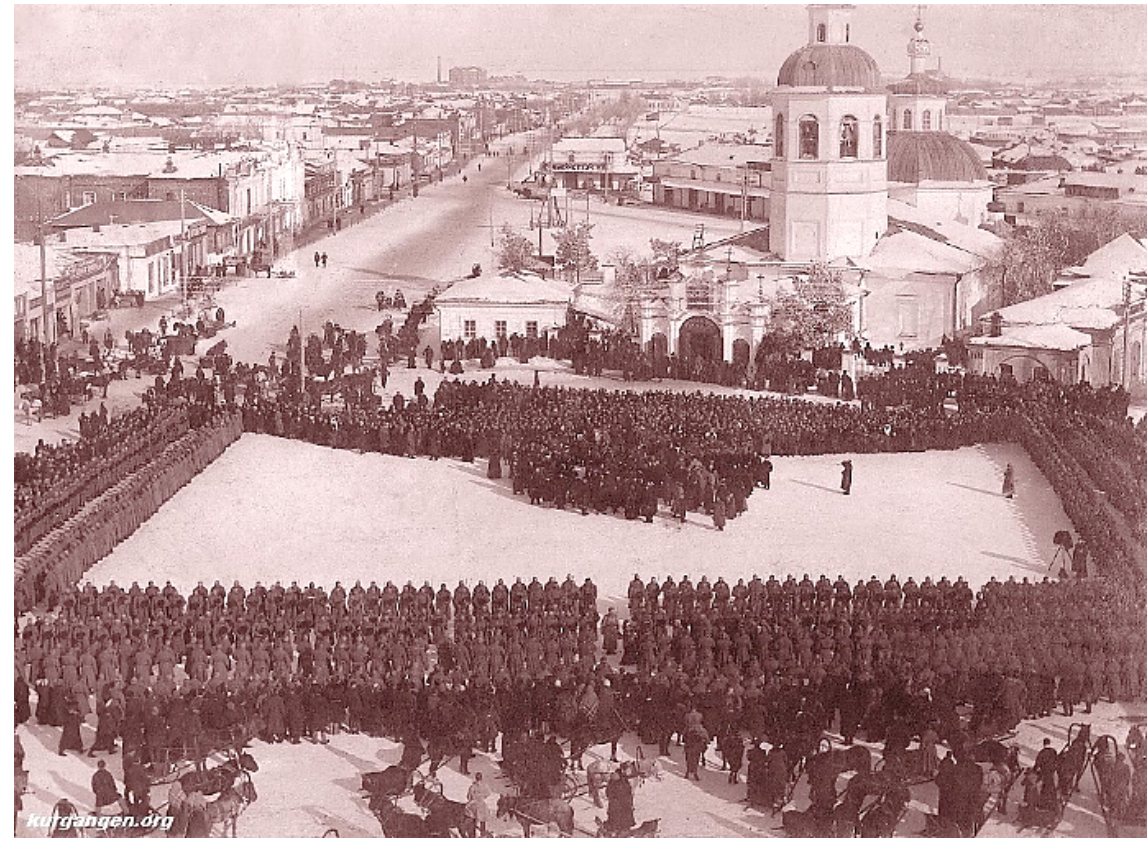

Рис. 1. Построение военного гарнизона на Троицкой площади в Кургане, начало XX в. (https://kurgan.pro/okn/n179/amp/).

\section{Изменение общей численности населения в 1915-1918 22.}

В начале 1916 г., судя по данным Всероссийской сельскохозяйственной переписи, в Тобольской губернии проживало 2191400 человек $^{8}$. Значит, в течение 1915 г. население увеличилось на 65708 человек, или на 3,1 \%. Рост численности населения в экстремальной обстановке войны был связан с сосредоточением в Зауралье мобилизованного в Сибири контингента военнообязанных лиц, наплывом беженцев из прифронтовой полосы, появлением в городах военнопленных. Однако в течение 1916 г. количество жителей в губернии заметно сократилось - на 239839 человек, или на 10,9 \%, и к 1 января 1917 г. в Тобольской губернии числился только 1951561 житель ${ }^{9}$ Конечно, такое падение численности насе-

\footnotetext{
${ }^{6}$ Зверев В.А. «Любо - так к венцу»: брачность русского населения Сибири во второй половине XIX - начале $\mathrm{XX}$ в. // Православные традиции в народной культуре восточнославянского населения Западной Сибири в конце XIX - XX в. Новосибирск, 2005. С. 9; Зверев В.А. «Родится на смерть, умрет на живот»: естественное движение населения Сибири за 30 лет (1884-1914) // Современное историческое сибиреведение XVII - начала ХХ в. Барнаул, 2008. Вып. 2. С. 111.

${ }^{7}$ Обзор Тобольской губернии за 1914 г. С. 5, 31.

${ }^{8}$ Население [Сибири]. / В.А. Зверев, В.А. Исупов, И.Б. Карпунина [и др.] // Историческая энциклопедия Сибири. Новосибирск, 2010. Т. 2. С. 435.

${ }^{9}$ Рощевский П.И. Тобольская губерния в годы Первой мировой империалистической войны (1914-1917) // Вопросы истории Западной Сибири. Тюмень, 1974. Т. 3. Вып. 1. С. 29-30.
} 
ления было тесно связано с интенсификацией призыва мужчин в армию, отправки на фронт и гибели многих из них. По данным историка Е.3. Волкова, в 1916 г. количество военных «отходников» с территории будущего Сибирского края достигло 613,5 тыс. человек, превысив в 1,8 раза аналогичный показатель 1915 г. и в 26 раз - показатель 1914 г. ${ }^{10}$ В отдельно взятой Тобольской губернии к началу 1917 г. призванными в армию числилось 223,7 тыс. душ ${ }^{11}$. В последующие два года масштабы «военного отхода» продолжали увеличиваться. В 1917 г. они в Сибири были в 1,3 раза больше, чем в предыдущем году, а в 1918 г. - в 1,2 раза больше, чем в 1917 г. ${ }^{12}$

В таких условиях логично предположить, что на заключительном этапе Первой мировой войны, в 1917 и 1918 гг., происходило дальнейшее сокращение численности населения Тобольской губернии. К сожалению, мы не располагаем статистикой, которая бы прямо подтвердила или опровергла это предположение. Однако историк П.И. Рощевский, раньше нас изучавший ситуацию, приблизительно определил минимальную меру убыли численности населения Тобольской губернии за 1914-1917 гг. в 204 тыс. человек, или в $10 \%{ }^{13}$. Если эта оценка верна, то в течение 1917 г. количество тобольских жителей должно было сократиться еще на 52,3 тыс. душ, или на 2,7 \%, и в начале 1918 г. составить около 1,9 млн человек.

Впрочем, и источниковедческая, и теоретическая обоснованность таких расчетов весьма проблематична. Даже механические (миграционные) факторы изменения общей численности населения в годы Первой мировой войны действовали разнонаправленно. «Военный отход» сокращал количество наличных тоболяков, но продолжавшаяся с довоенного времени, хотя и ставшая минимальной по масштабам, экономическая миграция из Европейской России, наплыв беженцев из западных губерний, депортация в Зауралье военнопленных, концентрация здесь контингентов действующей армии, а затем, начиная с 1917 г., стихийная демобилизация и возвращение домой военнослужащих способны были замедлять сокращение демографического потенциала или в определенные моменты даже увеличивать количество жителей восточных окраин России. По данным Е.3. Волкова, относящимся к территории Сибирского края, в 1917 г. только «наличие действующих армий» и «пришлого населения» здесь компенсировало «военный отход» на 56,1 \% ${ }^{14}$. Со временем совокупное воздействие позитивно направленных факторов могло усиливаться (рис. 2).

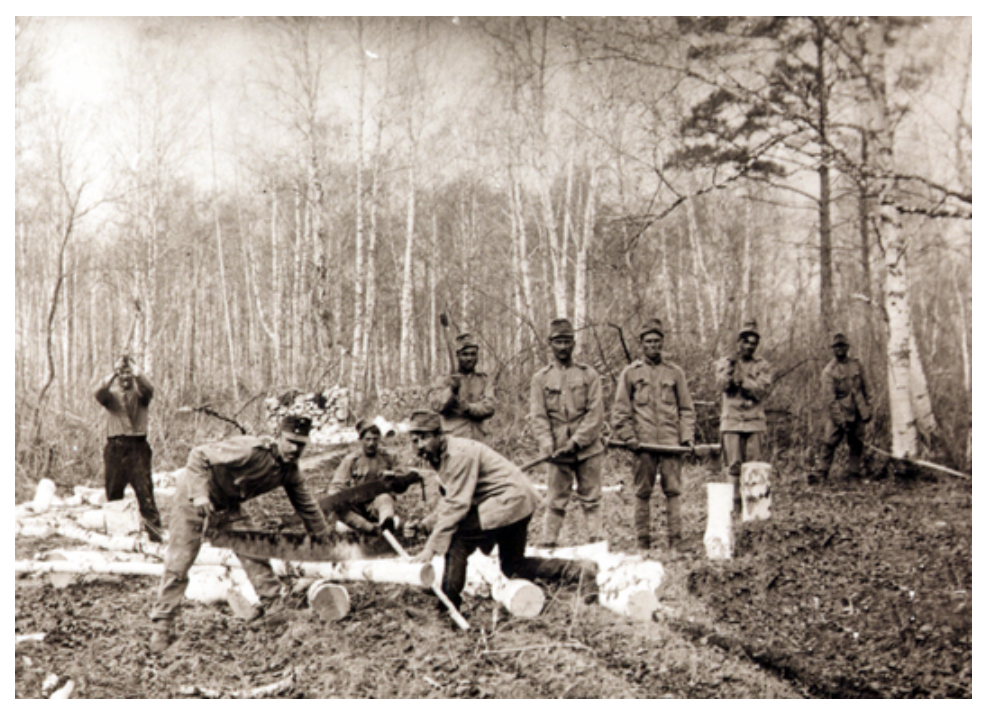

Puc. 2. Австро-венгерские военнопленные на заготовке дров в Зауралье, 1917 г. (http://nebel23.ucoz.ru/news/voennoplennye na kamenskom zavode v 1917 gdu/2015-02-11-57).

\footnotetext{
${ }^{10}$ Подсчитано по: Волков Е.З. Динамика народонаселения СССР за восемьдесят лет. М.; Л., 1930. С. 120.

${ }^{11}$ Рощевский П.И. Тобольская губерния в годы Первой мировой империалистической войны (1914-1917)... С. 30.

${ }^{12}$ Подсчитано по: Волков Е.З. Динамика народонаселения СССР... С. 120.

${ }_{13}^{13}$ Рощевский П.И. Тобольская губерния в годы Первой мировой империалистической войны (1914-1917)... С. 30.

${ }^{14}$ Подсчитано по: Волков Е.3. Динамика народонаселения СССР... С. 120.
} 


\section{Работа с церковными метрическими книгами Тарского уезда}

Динамика общей численности населения в изучаемом регионе - вопрос важный, но не центральный для историко-демографического исследования. Возвратимся теперь к проблематике воспроизводства населения Тобольской губернии, или его естественного движения в годы Первой мировой войны. Будем при этом иметь в виду, что соотношение параметров рождаемости и смертности, интегрированное в показателях естественного прироста населения - мощный фактор влияния на общую численность жителей, наряду с параметрами механического (миграционного) движения населения.

К сожалению, применительно к 1915-1918 гг. историки не располагают такими же обобщенными данными о естественном движении населения Тобольской губернии, какие мы имеем за 1914 г. По этой причине мы решили обратиться к первичным материалам текущего учета демографических событий - метрическим книгам православных церковных приходов. В глубоком сибирском тылу церковнослужители продолжали в годы войны и революции по случаю венчания браков, крещения новорожденных, отпевания усопших регистрировать факты брака, рождения и смерти прихожан. Полноту и точность этого учета никак нельзя признать безупречными, но его данные вполне можно использовать для сравнения ситуации предыдущих лет с последующими, ведь речь идет о документации, создаваемой из года в год теми же учреждениями и людьми с общей целью и по единой методике.

Работа с метрическими книгами для решения задач не локальной, а региональной истории весьма трудоемка: требуется просмотреть многие тысячи листов архивных документов, выявить и учесть (сгруппировать и суммировать) десятки тысяч сообщений о конкретных демографических событиях. В данном случае мы работали в ГБУТО «Государственный архив в г. Тобольске» с сохранившимся здесь комплексом метрических книг православных приходов Тарского уезда Тобольской губернии за 1912 и 1914-1918 гг. Количество браков, рождений и смертей тоболяков, зафиксированных в этих книгах, а также показатели объема естественного прироста, исчисленные как разность между количеством рождений и смертей, в сгруппированном и суммированном виде представлены в табл. 1.

Таблица 1

Абсолютное количество демографических событий, зафиксированных в церковных метрических книгах Тарского уезда*

\begin{tabular}{|l|c|c|c|c|c|c|}
\hline $\begin{array}{c}\text { Демографические } \\
\text { события }\end{array}$ & $\begin{array}{c}1912 \text { г. } \\
(21 \text { приход) }\end{array}$ & $\begin{array}{c}1914 \text { г. } \\
(23 \text { прихода) }\end{array}$ & $\begin{array}{c}1915 \text { г. } \\
(18 \text { приходов })\end{array}$ & $\begin{array}{c}1916 \text { г. } \\
(25 \text { приходов) }\end{array}$ & $\begin{array}{c}1917 \text { г. } \\
(25 \text { приходов) }\end{array}$ & $\begin{array}{c}1918 \text { г. } \\
(28 \text { приходов })\end{array}$ \\
\hline Браки & 327 & 500 & 207 & 230 & 466 & 1575 \\
\hline Рождения & 3320 & 3434 & 2359 & 2425 & 1999 & 4506 \\
\hline Смерти & 1935 & 2117 & 1880 & 2075 & 1487 & 2173 \\
\hline Прирост, чел. & 1385 & 1317 & 479 & 350 & 512 & 2333 \\
\hline
\end{tabular}

* Подсчитано по следующим источникам: Государственный архив в г. Тобольске. Ф. И-156 (Тобольская духовная консистория). Оп. 15. Д. 272. Л. 1-727; Д. 273. Л. 1-760; Д. 274. Л. 1-634; Д. 278. Л. 1-416; Д. 279. Л. 1-447; Д. 280. Л. 1-649; Д. 281. Л. 1-133; Д. 282. Л. 1-673; Д. 283. Л. 1-590; Д. 284. Л. 1-762; Д. 285. Л. 1691; Д. 286. Л. 1-600; Д. 287. Л. 1-1128; Д. 288. Л. 1-1863.

Отметим сразу, что материалы 1912 г. привлечены нами для сравнения предвоенной ситуации с обстановкой в военные годы. Обработанный архивный комплекс содержит информацию далеко не обо всем населении Тарского уезда, а только о некоторой его части, т.е. представляет из себя некую естественную выборку. Представляется, что эта выборка достаточно репрезентативна, поскольку в нее год за годом входит, как правило, более двух десятков церковных приходов. Следует акцентировать тот факт, что каждый год представлен различным количеством церквей (от 18 до 28), т.е. размеры выборки за разные годы отличаются. Поэтому сравнивать абсолютные числа, помещенные в табл. 1 в столбцах за каждый год, и делать на этом основании выводы о характере демографической динамики 
было бы неправильно. Проведем процедуру статистического «выравнивания» потенциала ежегодных данных. Сделаем это путем введения «поправочных» коэффициентов для каждого года. Взяв за единицу количество приходов, представивших сведения за 1912 г. (21), поделим 21 на количество приходов, представивших сведения за каждый военный год, и получим «поправочные» коэффициенты: для 1914 г. - 0,91; для 1915 г. - 1,17; для 1916 и 1917 гг. - по 0,84; для 1918 г. - 0,75. Затем помножим на эти коэффициенты все числа из соответствующих столбцов. Полученные таким образом данные сведены в табл. 2.

Таблица 2

Количество демографических событий в 21 условном церковном приходе Тарского уезда*

\begin{tabular}{|l|c|c|c|c|c|c|}
\hline $\begin{array}{c}\text { Демографические } \\
\text { события }\end{array}$ & 1912 г. & 1914 г. & 1915 г. & 1916 г. & 1917 г. & 1918 г. \\
\hline Браки & 327 & 455 & 242 & 193 & 391 & 1181 \\
\hline Рождения & 3320 & 3125 & 2760 & 2037 & 1679 & 3380 \\
\hline Смерти & 1935 & 1926 & 2200 & 1743 & 1249 & 1630 \\
\hline Прирост, чел. & 1385 & 1198 & 560 & 294 & 430 & 1750 \\
\hline
\end{tabular}

* Подсчитано по сведениям, представленным в табл. 1, с учетом «поправочных» коэффициентов.

Полученные таким образом показатели, относящиеся к каждому году, для удобства их сравнения друг с другом еще раз трансформируем. Представим данные 1912 г. как эталонные, приравняв их в каждой строчке к 100. Теперь путем решения нехитрых уравнений рассчитаем сравнительные масштабы брачности, рождаемости, смертности и естественного прироста населения за каждый военный год относительно масштабов 1912 г. (табл. 3).

Таблица 3

Относительное количество демографических событий, случившихся в Тарском уезде в период войны, по сравнению с уровнем 1912 г.*

\begin{tabular}{|l|c|c|c|c|c|c|}
\hline $\begin{array}{c}\text { Демографические } \\
\text { события }\end{array}$ & 1912 г. & 1914 г. & 1915 г. & 1916 г. & 1917 г. & 1918 г. \\
\hline Браки & 100 & 139,1 & 74 & 59 & 119,6 & 361,2 \\
\hline Рождения & 100 & 94,1 & 83,1 & 61,4 & 50,6 & 101,8 \\
\hline Смерти & 100 & 99,5 & 113,7 & 90,1 & 64,5 & 84,2 \\
\hline Прирост & 100 & 86,5 & 40,4 & 21,2 & 31 & 126,4 \\
\hline
\end{tabular}

* Подсчитано по сведениям, представленным в табл. 2.

\section{Естественное движение населения Тарского уезда в 1914-1918 г2.}

Опираясь на размещенные в табл. 3 данные, можно проследить изменения, происходившие ежегодно в различных сегментах воспроизводства населения Тарского округа в период Первой мировой войны.

Характеризуя динамику брачности, прежде всего отмечаем, что в 1914 г. в Тарском уезде произошел всплеск брачной активности населения: было сыграно почти на 40 \% свадеб больше, чем в довоенном 1912 г. Парни, подлежащие призыву в армию, спешили жениться, чтобы в родительские семьи на время войны привести дополнительную рабочую силу «молодух». Однако затем два года подряд уровень брачности населения снижался, в 1916 г. - почти наполовину по сравнению с 1912 г. Вследствие «военного отхода» в Зауралье оставалось мало женихов, политические, экономические и психологические обстоятельства военного времени заставляли тех, кто еще оставался, откладывать свадьбы до лучших времен. Но стихийная демобилизация части вооруженных сил в 1917 г., победа революции, выход России из войны в 1918 г. создали у значительной части населения 
иллюзию, что трудности уходят в прошлое, и возник компенсаторный подъем брачности. В 1918 г. тоболяки сыграли в 3,6 раза больше свадеб, чем в довоенный год.

Рождаемость в Тарском уезде, в отличие от брачности, после начала войны снижалась четыре года подряд, пока не достигла минимума в 1917 г. на уровне в два раза меньшем, чем в довоенном 1912 г. Однако возвращение в этом году с фронта части мужчин и оживление брачной активности привели к тому, что в 1918 г. количество родившихся младенцев поднялось до довоенного уровня.

Динамика смертности населения во время войны складывалась противоречиво. С одной стороны, экстремальные политические, психологические, социальные и хозяйственные проблемы, резкое увеличение доли в населении детей и стариков провоцировали усиление смертности, и своего пика в Тарском уезде она достигла в 1915 г. С другой стороны, сокращение рождаемости влекло за собой и снижение мортальности, ведь больше половины всех умерших даже в мирные годы на излете имперской истории давали младенцы, не достигшие и годовалого возраста. Не родившись, они не могли и умереть. Поэтому господствовавшей демографической тенденцией в годы Первой мировой войны было все же сокращение смертности. В 1917 г. она была уже более чем на треть ниже, чем в 1912 г. В 1918 г. мортальность немного подросла, но до довоенных масштабов ей было еще далеко.

Естественный прирост населения - процесс, интегрирующий рождаемость и смертность. Поскольку в Тарском уезде в годы войны рождаемость сокращалась быстрее и более последовательно, чем смертность, естественный прирост населения уменьшался и в 1916-1917 гг. составил всего 20-30 \% от довоенного уровня. Правда, в 1918 г. вследствие всплеска компенсаторной рождаемости прирост на четверть превысил довоенные параметры.

\section{Частичная верификация и общие итоги исследования}

У внимательного читателя может возникнуть вопрос: а не объясняются ли зафиксированные в табл. 2, 3 и прокомментированные нами изменения параметров естественного движения населения просто колебаниями общего количества жителей Тарского Прииртышья. Ведь чем многочисленнее население, тем больше в нем может произойти демографических событий, и наоборот. Чтобы проверить это предположение, можно применить метод корреляционного анализа парных зависимостей: ввести в сравнение динамические погодовые ряды абсолютных показателей рождаемости и смертности с рядом ежегодных величин общей численности населения. Но известные нам источники не дают сведений о количестве жителей в Тарском уезде в 1915-1918 гг. Ничего не остается, кроме того, чтобы хотя бы для приблизительных расчетов использовать данные о менявшейся в эти годы численности населения всей Тобольской губернии.

Нами был проведен корреляционный анализ парных зависимостей между погодовым динамическим рядом абсолютных показателей численности населения Тобольской губернии в диапазоне 1914-1918 гг. (на начало каждого года) и соответствующими рядами абсолютных показателей количества демографических событий, произошедших в эти годы в Тарском уезде. Зависимость между численностью населения и количеством умерших оказалась средней, с коэффициентом линейной корреляции, равным 0,63. Линейная корреляция между динамикой рождаемости, с одной стороны, и изменением численности населения, с другой, оказалась отрицательной, с коэффициентом, равным -0,19. Это означает, что количество рождений и уровень естественного прироста сокращались, когда численность населения росла, и наоборот, но даже такая обратная связь здесь была слабой. Можно сделать осторожный вывод о том, что естественное движение населения Тарского уезда в годы Первой мировой войны имело собственную логику, не связанную или слабо связанную с колебаниями общей численности населения. Вывод этот нуждается в дополнительной проверке, возможной в случае обнаружения или создания базы статистических данных о численности населения в Тарском уезде в начале каждого из военных лет.

Сегодня же можно с уверенностью констатировать, что период Первой мировой войны был кризисным для системы воспроизводства населения в Тобольской губернии, как и в 
целом для Сибири, для всей России. Судя по официальным данным главного медицинского ведомства страны и материалам первичного церковного учета демографических событий в Тарском уезде, в начале войны, в 1914 г., все параметры естественного движения населения были относительно благоприятными для возобновления поколений тоболяков. Однако в 1915-1917 гг. в Тарском уезде показатели рождаемости и естественного прироста населения сократились в несколько раз. Смертность подскочила в 1915 г., а последующее ее снижение было производным от сокращения рождаемости. Брачность - единственная демографическая сфера, которая в компенсаторном порядке, вследствие частичной демобилизации армии и общественного подъема в городах, вышла из кризиса уже в 1917 г. Она потянула за собой временное улучшение всех демографических показателей в 1918 г. Относительно благоприятная демографическая ситуация, сложившаяся в последний год мировой войны, в исторической перспективе оказалась только передышкой в ходе демографического кризиса, продолжавшегося до 1923 г.

\section{Jumepamypa}

Волков Е.3. Динамика народонаселения СССР за восемьдесят лет. М.; Л.: Гос. изд-во, 1930. 271 c.

Демографическая история Западной Сибири / отв. ред. В.А. Исупов. Новосибирск: Институт истории СО РАН, 2017. 350 с.

Зверев В.А. «Любо - так к венцу»: брачность русского населения Сибири во второй половине XIX - начале XX в. // Православные традиции в народной культуре восточнославянского населения Западной Сибири в конце XIX - XX в. Новосибирск: Изд-во ИАЭТ СО PAH, 2005. C. 7-17.

Зверев В.А. «Родится на смерть, умрет на живот»: естественное движение населения Сибири за 30 лет (1884-1914) // Современное историческое сибиреведение XVII - начала ХХ в. Барнаул: Азбука, 2008. Вып. 2. С. 107-124.

Зверев B.A. «Ну, посчитаемся своими»: демографические и миграционные процессы в Азиатской России XIX - начала XX в.// Проблемы исторической демографии Сибири. Новосибирск: Параллель, 2011. Вып. 2. С. 42-68.

Меньщиков В.Н. Экономическое и социокультурное развитие Тобольской губернии в период Первой мировой войны, 1914-1917 гг.: автореф. дис. ... канд. ист. наук. Омск, 2001. 23 с.

Население [Сибири] / В.А. Зверев, В.А. Исупов, И.Б. Карпунина, А.П. Мелентьева, С.Г. Скобелев, С.В. Соболева // Историческая энциклопедия Сибири. Новосибирск: Ист. наследие Сибири, 2010. Т. 2. С. 434-441.

Рощевский П.И. Тобольская губерния в годы Первой мировой империалистической войны (1914-1917) // Вопросы истории Западной Сибири. Тюмень: ТюмГУ, 1974. Т. 3. Вып. 1. С. 24-33.

Шишкина С.Ю. Провинция и война: Тобольская губерния в годы Первой мировой войны (август 1914 - февраль 1917). Тюмень: ТОГИРРО, 2006. 208 с.

\section{References}

Isupov, V.A. (Ed.) (2017). Demograficheskaya istoriya Zapadnoy Sibiri (konets XIX - XX v.) [Demographic history of Western Siberia (end of $19^{\text {th }}-20^{\text {th }}$ centuries)]. Novosibirsk, Institute of history SB RAS. 350 p.

Menshchikov, V.N. (2001). Ekonomicheskoye i sotsiokul'turnoye razvitiye Tobol'skoy gubernii v period Pervoi mirovoy voyny, 1914-1917 gg. [Economic and sociocultural development of Tobol province during the First World War, 1914-1917], Cand. hist. sci. diss. abstract. Omsk, 23 p.

Roshchevskiy, P.I. (1974). Tobol'skaya guberniya v gody Pervoi mirovoi imperialisticheskoi voiny (1914-1917) [Tobolsk province during the First World Imperial War (1914-1917)]. In Voprosy istorii Zapadnoi Sibiri. Vol. 3. No. 1, pp. 24-33. 
Shishkina, S.Yu. (2006). Provintsiya i voina: Tobol'skaya guberniya v gody Pervoi mirovoi voiny (avgust 1914 - fevral' 1917) [Province and war: Tobol province during World War I (August 1914 - February 1917)]. Tyumen, Tyumen Regional State Institute for regional education development, $208 \mathrm{p}$.

Volkov, E.Z. (1930). Dinamika narodonaseleniya SSSR za vosem'desyat let [Eighty years of population dynamics of the USSR]. Moscow; Leningrad, State Publishing House. 271 p.

Zverev, V.A. (2005). "Lyubo - tak k ventsu”: brachnost' russkogo naseleniya Sibiri vo vtoroi polovine XIX - nachale XX v. ["Lubo - so to the crown": the marriage of the Russian population of Siberia in the second half of the $19^{\text {th }}$ - early $20^{\text {th }}$ Century]. In Pravoslavniye traditsii $v$ narodnoy kul'ture vostochnoslavyanskogo naseleniya Zapadnoy Sibiri v kontse XIX $-X X v$. Novosibirsk, pp. 7-17.

Zverev, V.A. (2008). "Roditsya na smert', umret na zhivot”: estestvennoe dvizheniye naseleniya Sibiri za 30 let (1884-1914) ["Born to death, dies on his stomach": the natural movement of the population of Siberia for 30 years (1884-1914)]. In Sovremennoye istoricheskoye sibirevedenie XVII - nachala XX v. Barnaul, vol. 2, pp. 107-124.

Zverev, V.A. (2011). “Nu, poschitaemsya svoimi”: demograficheskie i migratsionnye protsessy v Aziatskoi Rossii XIX - nachala XX v. [“Well, let's reckon our own”: demographic and migration processes in Asian Russia of the $19^{\text {th }}$ early $20^{\text {th }}$ Century.]. In Problemy istoricheskoi demografii Sibiri. Novosibirsk, vol. 2, pp. 42-68.

Zverev, V.A., Isupov, V.A., Karpunina, I.B., Melent'eva, A.P., Skobelev, S.G., Soboleva, S.V. (2010). Naselenie [Sibiri] [“The population of Siberia”]. In Istoricheskaya entsiklopediya Sibiri. Novosibirsk, vol. 2, pp. 434-441.

Статья поступила в редакцию 31.12.2019 г. 